\title{
Mekanisme Adaptasi Jagung terhadap Cekaman NaCl: Pola Serapan Anion dan Kation
}

\author{
Adaptation Mechanism of Maize on NaCl Stress: \\ Anion and Cation Absorption Patterns \\ Muhammad Zulman Harja Utama* dan Widodo Haryoko \\ Prodi Agroteknologi, Fakultas Pertanian, Universitas Tamansiswa, Padang \\ Jl. Tamansiswa No. 9 Padang 25136, Indonesia
}

Diterima 4 Maret 2019/Disetujui 22 Oktober 2019

\begin{abstract}
Salt solubility is the abiotic pressure which has the most effect on the loss of plant quantity and quality. Salinity not only makes plants stressful but also presents severe constraints on crop production so an attempt to understand plant adaptation mechanisms is important for expanding agricultural production on saline soils. This study aimed to obtain a mechanism for the adaptation of hybrid and composites maize to $\mathrm{NaCl}$ stress through anion and cation absorption patterns. The experiments were carried out at the LLDikti Region X Laboratory from May to August 2016. The experiments were arranged in a factorial complete randomized design with three replications. The first factor was corn varieties, namely: hybrid corn (Pioneer 22 and Bisi 12), and composite corn (Bisma and Sukmaraga). The second factor was level of $\mathrm{NaCl}$, namely: $0.0 \mathrm{mg} \mathrm{kg} \mathrm{NaCl} \mathrm{pH}^{-1}$ 5.0, and 4,000 $\mathrm{mg} \mathrm{kg}^{-1} \mathrm{NaCl} \mathrm{pH} \mathrm{5.0.} \mathrm{Measurement} \mathrm{of} \mathrm{anions} \mathrm{and} \mathrm{cations} \mathrm{using} \mathrm{Spectroquant} \mathrm{Thermoreator} \mathrm{TR} \mathrm{Nova} \mathrm{420.} \mathrm{The}$ adaptability of hybrid maize and composites to $\mathrm{NaCl}$ stress occurred through the mechanism of anion absorption and cation metabolism. The difference in the percentage of NO3-, NO2-, PO4-, NH4+, and $\mathrm{K}+$ levels between hybrid maize varieties and composites showed a difference in the adaptation ability of maize varieties to salinity stress.
\end{abstract}

Keywords: abiotic, mechanism, salinity, varieties

\section{ABSTRAK}

Kelarutan garam adalah tekanan abiotik yang paling berpengaruh pada kerugian kuantitas dan kualitas tanaman. Salinitas tidak hanya membuat tanaman stres tetapi juga menghadirkan kendala berat pada budidaya tanaman sehingga usaha untuk memahami strategi adaptasi tanaman adalah hal penting untuk memperluas produksi pertanian pada tanah salin. Penelitian ini bertujuan untuk mendapatkan mekanisme adaptasi jagung hibrida dan komposit terhadap cekaman $\mathrm{NaCl}$ melalui pola serapan anion dan kation. Percobaan dilaksanakan di Laboratorium LLDikti Wilayah X dari bulan Mei sampai Agustus 2016. Percobaan disusun secara faktorial, menggunakan rancangan acak lengkap, dengan tiga ulangan. Faktor pertama adalah varietas jagung, yaitu: jagung hibrida (Pioneer 22 dan Bisi 12), dan jagung komposit (Bisma dan Sukmaraga). Faktor kedua adalah $\mathrm{NaCl}$, yaitu: $0.0 \mathrm{mg} \mathrm{kg}^{-1} \mathrm{NaCl} \mathrm{pH} \mathrm{5.0,} \mathrm{dan} \mathrm{4,000} \mathrm{mg} \mathrm{kg}^{-1} \mathrm{NaCl} \mathrm{pH} \mathrm{5.0.} \mathrm{Pengukuran} \mathrm{anion}$ dan kation menggunakan spectroquant thermoreator TR Nova 420. Kemampuan adaptasi jagung hibrida dan komposit terhadap cekaman $\mathrm{NaCl}$ terjadi melalui mekanisme metabolisme serapan anion dan kation. Perbedaan persentase kadar $\mathrm{NO}_{3}^{-}, \mathrm{NO}_{2}^{-}, \mathrm{PO}_{4}^{-}, \mathrm{NH}_{4}^{+}$, dan $\mathrm{K}^{+}$antara varietas jagung hibrida dan komposit, menunjukkan perbedaan kemampuan adaptasi varietas jagung terhadap cekaman salinitas.

Kata kunci: abiotik, mekanisme, salin, varietas

\section{PENDAHULUAN}

Kelarutan garam $(\mathrm{NaCl})$ yang tinggi adalah tekanan abiotik yang paling berpengaruh pada kerugian kuantitas

\footnotetext{
* Penulis untuk korespondensi. e-mail: harja65@yahoo.com
}

dan kualitas tanaman. Perubahan iklim dan degradasi lingkungan tanah, salinitas tanah diperkirakan dalam waktu 25 tahun mendatang akan menyebabkan 30\% kerugian tanah di seluruh dunia (Lashari et al., 2018). Tanah salin merupakan salah satu masalah paling serius yang dihadapi dalam budidaya tanaman yang berkelanjutan. Salinitas tidak hanya membuat tanaman stres tetapi juga menghadirkan 
kendala berat pada budidaya tanaman sehingga usaha untuk memahami strategi adaptasi tanaman adalah hal yang penting untuk memperluas produksi pertanian pada tanah salin (Ismail et al., 2014). Luas daratan Indonesia tidak kurang dari 191.09 juta ha, dari luasan tersebut sekitar 95.90 juta ha atau $50.19 \%$ potensial untuk pertanian dengan potensi luas lahan tersedia untuk pangan seluas 14.74 juta ha (Ritung et al., 2015). Dari luasan lahan tersebut, lahan yang tercekam salinitas belum terinventarisasi dan terdeleniasi dalam sebuah data spasial, tetapi dampaknya telah dirasakan oleh petani (Rachman et al., 2018). Kerugian hasil panen karena cekaman salinitas mencapai $65-87 \%$, bahkan pada tanaman padi dapat mencapai $90 \%$ (Ismail et al., 2014; Putri et al., 2017; Rachman et al., 2018).

Evolusi tumbuhan telah menghasilkan berbagai mekanisme adaptasi secara internal maupun eksternal untuk mentoleransi cekaman yang terkait dengan peningkatan salinitas tanah. Namun, untuk sebagian besar tanaman sereal, pertumbuhan akar menjadi terganggu ketika salinitas tanah lebih dari $4 \mathrm{dS} / \mathrm{m}$, setara dengan $40 \mathrm{mM} \mathrm{NaCl}$ (Munns dan Tester, 2008). Meningkatnya salinitas tanah menyebabkan tanaman keracunan ion natrium $\left(\mathrm{Na}^{+}\right)$dan klorida $\left(\mathrm{Cl}^{-}\right)$, yang menimbulkan cekaman ion dan osmotik dari stres $\mathrm{NaCl}$ (Byrt et al., 2018). Kinerja tanaman dipengaruhi oleh konsentrasi kelarutan $\mathrm{NaCl}$ yang terdapat di daerah rhizosfer perakaran tanaman. Pada kondisi kelebihan $\mathrm{NaCl}$ di tanah maka akan menyebabkan terhambatnya proses fotosintesis dan pengangkutan air oleh akar dan hara nutrisi (Chen et al., 2017).

Tumbuhan toleran $\mathrm{NaCl}$ menunjukkan komponen penanda dan pemberian sinyal stres, transportasi $\mathrm{Na}^{+}$dan jalur detoksifikasi serta dampak dari modifikasi kromatin epigenetik yang berperan penting dalam mengatur respons stres salinitas tanaman (Deinlein et al., 2014). Rekayasa tanaman yang toleran terhadap cekaman $\mathrm{NaCl}$ adalah hal yang sangat penting karena itu, perlu diketahui mekanisme toleransinya (Munns et al., 2019).

Upaya meningkatkan pertumbuhan dan menetralkan pengaruh buruk $\mathrm{Na}^{+}$sangat penting untuk peningkatan pertumbuhan tanaman (Demidchik et al., 2017; Gharbi et al., 2017a), khususnya pada budidaya di lahan rawa dengan kadar $\mathrm{NaCl}$ tinggi (Utama, 2010). Tanaman toleran mempunyai kemampuan beradaptasi secara morfologi maupun fisiologi (Rustikawati et al., 2014; Gharbi et al., 2017b).

Potensi lahan marginal yang dapat dimanfaatkan untuk budidaya pertanian antara lain adalah lahan rawa. Indonesia memiliki lahan rawa lebih dari 33 juta ha (Susanto, 2019), dari luasan lahan tersebut baru sekitar 4.2 juta ha yang telah dimanfaatkan. Rendahnya pemanfaatan lahan rawa tersebut karena terbatasnya teknologi dan varietas toleran terhadap cekaman. Untuk memanfaatkan lahan rawa tersebut diperlukan adanya program seleksi varietas jagung untuk menghasilkan tanaman yang toleran terhadap cekaman lingkungan seperti salinitas tinggi (Utama, 2009).

Permasalahan penting dalam budidaya tanaman jagung di lahan salin kawasan rawa pantai adalah keracunan $\mathrm{Na}^{+}$. Gharbi et al., 2017a; Zorb et al., 2019, mengemukakan cekaman $\mathrm{Na}^{+}$menyebabkan kerusakan sel tanaman dan defisit air sehingga pertumbuhan tanaman terhambat. Pada tanah salin, hambatan pertumbuhan semakin meningkat terutama pada kondisi air pasang dan musim kemarau, menyebabkan rendahnya kelarutan hara esensial sehingga terjadi kekahatan (Sahrawat, 2010; Haryoko et al., 2012).

Jagungmerupakan tanamanyang memiliki kemampuan beradaptasi terhadap berbagai jenis cekaman termasuk cekaman salinitas. Mekanisme tanaman beradaptasi terhadap cekaman terjadi melalui mekanisme eksternal dan internal (Shabala et al., 2006; Munns dan Tester, 2008). Mekanisme eksternal adalah sistem toleransi yang dibangun oleh tanaman dengan cara mencegah masuknya sumber cekaman, sedangkan mekanisme toleransi internal adalah mekanisme untuk mencegah masuknya sumber cekaman yang sudah memasuki sistem simplas, merusak sel, dengan cara kelat di sitosol, kompartemen di vakuola, sintesis protein pengikat, sintesis enzim yang tahan dan peningkatan aktivitas enzim. Mekanisme toleransi juga dapat terjadi melalui proses metabolisme dengan berbagai bentuk serapan phytohormone dan nitrogen, seperti nitrat, amonium dan nitrit (Munns dan Gilliham, 2015; Gharbi et al., 2017b; Pongprayoon et al., 2019).

Penelitian tentang mekanisme adaptasi jagung hibrida dan komposit tercekam $\mathrm{NaCl}$ terhadap pola serapan anion dan kation masih sangat kurang, sehingga dari penelitian ini diperoleh informasi lebih lengkap tentang mekanisme serapan $\mathrm{NO}_{3}^{-}, \mathrm{NO}_{2}^{-}, \mathrm{PO}_{4}^{-}, \mathrm{NH}_{4}^{+}$, dan $\mathrm{K}^{+}$. Kemampuan tanaman dalam menyerap anion dan kation (Utama, 2008), dapat mempengaruhi adaptasi tanaman terhadap cekaman $\mathrm{NaCl}$ (Demidchik et al., 2014; Shabala et al., 2006; Chen et al., 2017). Tujuan penelitian adalah memahami mekanisme adaptasi tanaman jagung untuk memperluas produksi pertanian pada tanah yang terkena cekaman $\mathrm{NaCl}$.

\section{BAHAN DAN METODE}

Percobaan dilaksanakan di Laboratorium LLDikti Wilayah X dari bulan Mei sampai Agustus 2016. Varietas jagung hibrida yang digunakan adalah Pioneer 22 dan Bisi 12 , sedangkan varietas jagung komposit, yaitu Bisma dan Sukmaraga. Percobaan faktorial dua faktor menggunakan rancangan acak lengkap, dengan tiga ulangan. Faktor pertama adalah varietas jagung, yaitu Pioneer 22, Bisi 12, Bisma dan Sukmaraga. Faktor kedua adalah konsentrasi $\mathrm{NaCl}$, yaitu $0.0 \mathrm{mg} \mathrm{kg} \mathrm{NaCl}$ pada $\mathrm{pH} 5.0$ (kontrol), dan 4,000 $\mathrm{mg} \mathrm{kg}^{-1} \mathrm{NaCl}$ pada pH 5.0 (Utama et al., 2009).

Kecambah jagung yang digunakan memiliki panjang akar $3 \mathrm{~cm}$. Sebelum dikecambahkan benih jagung direndam dalam larutan fungisida deltametrin dengan konsentrasi 3 g per liter selama 15 menit. Selanjutnya, benih jagung dibilas sampai bersih dan direndam selama 12 jam dan dikecambahkan selama 1 minggu dalam bak plastik berlubang dengan media kertas merang pada suhu kamar. Media kultur menggunakan komposisi hara terdiri dari: 1.5 $\mathrm{mM} \mathrm{Ca}\left(\mathrm{NO}_{3}\right)_{2} 4 \mathrm{H}_{2} 0,1.0 \mathrm{mM} \mathrm{NH}_{4} \mathrm{NO}_{3}, 1.0 \mathrm{mM} \mathrm{KCl}, 0.4$ $\mathrm{mM} \mathrm{MgS0}{ }_{4} .7 \mathrm{H}_{2} 0,1.0 \mathrm{mM} \mathrm{KH}_{2} \mathrm{PO}_{4}, 0.50 \mathrm{mg} \mathrm{kg}^{-1} \mathrm{MnSO}_{4}$. $\mathrm{H}_{2} \mathrm{O}, 0.02 \mathrm{mg} \mathrm{kg}^{-1} \mathrm{CuSO}_{4} .5 \mathrm{H}_{2} \mathrm{O}, 0.05 \mathrm{mg} \mathrm{kg}^{-1} \mathrm{ZnSO}_{4} .7 \mathrm{H}_{2} \mathrm{O}$, 
$0.50 \mathrm{mg} \mathrm{kg}^{-1} \mathrm{H}_{3} \mathrm{BO}_{3}, 0.01 \mathrm{mg} \mathrm{kg}^{-1}\left(\mathrm{NH}_{4}\right)_{6} \mathrm{Mo}_{7} \mathrm{O}_{24} \cdot 4 \mathrm{H}_{2} \mathrm{O}$, dan $\mathrm{NaCl}$ (Utama, 2010).

Kecambah jagung ditumbuhkan dalam bak plastik berisi 2.5 liter larutan hara tanpa $\mathrm{NaCl}$ pada $\mathrm{pH}$ 5.0. Media adaptasi menggunakan larutan hara tanpa $\mathrm{NaCl}$ dengan pH 4.0 selama 7 hari, setelah itu benih jagung tersebut ditumbuhkan pada larutan hara dengan $\mathrm{pH} 5.0$ dan cekaman $\mathrm{NaCl}$ sesuai perlakuan. Pergantian larutan hara dilakukan setiap 7 hari sekali dan selama percobaan berlangsung larutan hara dialiri udara menggunakan aerator. Pada setiap baki plastik terdapat 5 tanaman dengan penyangga dari styrofoam yang diberi lubang sebanyak 5 buah, dan tanaman tersebut dibalut dengan kapas steril pada bagian pangkal batang. Tanaman dipanen untuk dilakukan pengamatan 28 hari setelah tanam dalam media kultur.

Berangkasan tanaman dikeringkan, ditimbang, lalu digiling untuk analisis serapan anion dan kation berupa $\mathrm{NO}_{3}^{-}, \mathrm{NO}_{2}^{-}, \mathrm{PO}_{4}^{-}, \mathrm{NH}_{4}^{+}$, dan $\mathrm{K}^{+}$. Sampel tanaman ditimbang sebanyak $0.5 \mathrm{~g}$, kemudian didestruksi dengan $\mathrm{H}_{2} \mathrm{SO}_{4}$, $\mathrm{HClO}_{4}$, dan $\mathrm{HNO}_{3}$ pekat lalu dipanaskan sampai jernih. Cara kerjanya tabung larutan standar berbarcode dimasukkan sesuai dengan anion dan kation yang diukur. Larutan standar dimasukkan Spectroquant Thermoreaktor TR Nova 420 dan disiapkan larutan test kid $\left(\mathrm{NO}_{3}^{-}, \mathrm{NO}_{2}^{-}, \mathrm{PO}_{4}^{-}, \mathrm{NH}_{4}^{+}\right.$, dan $\mathrm{K}^{+}$) dan ditambahkan larutan sampel $2 \mathrm{ml}$ pada setiap larutan test kid dan didiamkan selama 10 menit. Campuran test kid dimasukkan dalam kuvet kristal ukuran $10 \mathrm{ml}$ dan dilakukan pembacaan dengan Spectroquant Thermoreaktor TR Nova 420 (Merck, 2007).

\section{HASIL DAN PEMBAHASAN}

Hasil analisis kadar nitrat $\left(\mathrm{NO}_{3}^{-}\right)$, amonium $\left(\mathrm{NH}_{4}^{+}\right)$, nitrit $\left(\mathrm{NO}_{2}^{-}\right)$, kalium $\left(\mathrm{K}^{+}\right)$, dan pospor $\left(\mathrm{PO}_{4}^{-}\right)$pada jagung hibrida (Pioneer 22 dan Bisi 12) dan jagung komposit (Bisma dan Sukmaraga) pada perlakuan cekaman garam pada kultur hara, berturut-turut disajikan pada Tabel 1, 2, dan 3. Hasil analisis menginformasikan bahwa tidak ada hambatan penyerapan oleh ke empat varietas jagung terhadap kadar $\mathrm{NO}_{3}^{-}, \mathrm{NH}_{4}^{+}, \mathrm{NO}_{2}^{-}, \mathrm{K}^{+}$dan $\mathrm{PO}_{4}$.

Kadar $\mathrm{NO}_{3}^{-}$pada varietas Bisi 12 dan Bisma dalam kondisi tercekam $\mathrm{NaCl}$ lebih tinggi dibandingkan pada kondisi tanpa cekaman, yaitu meningkat berturut-turut
1.1 dan 15.5 kali. Hal ini, sangat berbeda dengan varietas Pioneer 22 dan Sukmaraga, terjadi penurunan kadar $\mathrm{NO}_{3}{ }_{3}$ berturut-turut, yaitu 0.29 dan 0.30 kali. Kadar $\mathrm{NO}_{3}{ }^{-}$tertinggi pada perlakuan garam terjadi pada varietas Bisma yaitu $0.066 \%$, sedangkan kadar terendah pada varietas Pioneer 22 , yaitu $0.029 \%$ (Tabel 1). Perbedaannya terlihat pada konsentrasi serapan anion dan kation dalam kondisi normal dan tercekam, yang diduga mempengaruhi mekanisme adaptasi secara fisiologi.

Tabel 1 juga menunjukkan perbedaan yang nyata kadar $\mathrm{NH}_{4}^{+}$ke empat varietas jagung. Varietas Pioneer 22 dan Bisma pada kondisi tercekam $\mathrm{NaCl}$ memperlihatkan selisih kadar $\mathrm{NH}_{4}^{+}$yang meningkat dibandingkan pada kondisi tanpa cekaman yaitu masing-masing 4.39 dan $1.43 \mathrm{kali}$, sedangkan varietas Bisi 12 dan Sukmaraga cenderung memiliki kadar $\mathrm{NH}_{4}^{+}$lebih rendah yaitu masing-masing 2.60 dan 0.67 kali. Pada parameter ini, terjadi pola respons yang berbeda pada varietas Pioneer 22 dan Bisi 12 jika dibandingkan dengan penyerapan kadar $\mathrm{NO}_{3}$. Peningkatan persentase kadar $\mathrm{NH}_{4}^{+}$ tertinggi pada perlakuan $\mathrm{NaCl}$ terjadi pada varietas Pioneer 22 yaitu 4.39 kali, tetapi tidak terdeteksi pada varietas Bisi 12. $\mathrm{Kadar} \mathrm{NH}_{4}^{+}$yang tidak terdeteksi diduga terjadi sebagai akibat perubahan yang cepat dari $\mathrm{NH}_{4}^{+}$menjadi $\mathrm{NH}_{2}$ yang diperlukan untuk pembentukan senyawa protein.

Hasil analisis yang disajikan pada Tabel 2 memperlihatkan adanya keragaman kadar $\mathrm{NO}_{2}^{-}$. Varietas Bisma dalam kondisi tercekam $\mathrm{NaCl}$ mengalami kecenderungan peningkatan kadar $\mathrm{NO}_{2}^{-}$dibandingkan tanpa cekaman yaitu 0.36 kali, sedangkan varietas Pioneer 22, Bisi 12, dan Sukmaraga cenderung mengalami penurunan kadar $\mathrm{NO}_{2}^{-}$masing-masing $0.22 ; 0.22$ dan 0.42 kali. Persentase kadar $\mathrm{NO}_{2}^{-}$tertinggi pada kondisi stres $\mathrm{NaCl}$ yaitu $0.015 \%$ pada varietas jagung Bisma, dan sebaliknya kadar $\mathrm{NO}_{2}$ terendah pada varietas jagung Sukmaraga yaitu $0.011 \%$.

Perbedaan persentase kadar ion yang diserap oleh setiap varietas jagung tersebut menginformasikan keragaman jagung dalam beradaptasi terhadap cekaman salinitas. Tanaman sereal umumnya telah mengalami cekaman pada kondisi kelarutan $\mathrm{NaCl}$ setara dengan $40 \mathrm{mM}$ (Zorb et al., 2019). Kemampuan tanaman jagung dalam menyerap berbagai bentuk $\mathrm{N}$, akan mempengaruhi kemampuan dari tanaman dalam beradaptasi terhadap cekaman salinitas, demikian juga dengan kemampuan dalam menyerap unsur

Tabel 1. Persentase kadar $\mathrm{NO}_{3}^{-}$dan $\mathrm{NH}_{4}^{+}$pada beberapa varietas jagung tercekam $\mathrm{NaCl}$ umur 3 MST pada kultur hara

\begin{tabular}{|c|c|c|c|c|}
\hline $\begin{array}{l}\text { Konsentrasi } \\
\mathrm{NaCl}\left(\mathrm{mg} \mathrm{kg}^{-1}\right) \\
\end{array}$ & Pioneer 22 & Bisi 12 & Bisma & Sukmaraga \\
\hline & \multicolumn{4}{|c|}{$\mathrm{NO}_{3}^{-}(\%)$} \\
\hline 0 (kontrol) & $0.04 \mathrm{ab}$ & $0.02 b$ & $0.00 \mathrm{ab}$ & $0.05 \mathrm{ab}$ \\
\hline \multirow[t]{2}{*}{4,000} & $0.03 b$ & $0.05 \mathrm{ab}$ & $0.05 \mathrm{a}$ & $0.03 b$ \\
\hline & & ㄱ..…....... & & \\
\hline 0 & $0.13 \mathrm{c}$ & $2.60 \mathrm{a}$ & $0.30 \mathrm{bc}$ & $1.20 \mathrm{ab}$ \\
\hline 4,000 & $0.70 b c$ & $0.00 \mathrm{c}$ & $0.73 b c$ & $0.40 \mathrm{bc}$ \\
\hline
\end{tabular}

Keterangan: Angka diikuti huruf berbeda pada peubah yang sama pada masing-masing perlakuan menunjukkan berbeda nyata pada taraf 5\% dengan uji Tukey 
Tabel 2. Persentase kadar $\mathrm{NO}_{2}^{-}$pada beberapa varietas jagung tercekam $\mathrm{NaCl}$ umur $3 \mathrm{MST}$ pada kultur hara

\begin{tabular}{|c|c|c|c|c|}
\hline $\begin{array}{l}\text { Konsentrasi } \\
\mathrm{NaCl}\left(\mathrm{mg} \mathrm{kg}^{-1}\right)\end{array}$ & Pioneer 22 & Bisi 12 & Bisma & Sukmaraga \\
\hline & \multicolumn{4}{|c|}{$\ldots \ldots \ldots \mathrm{NO}_{2}^{-}(\%)$} \\
\hline 0 & $0.018 \mathrm{ab}$ & $0.018 \mathrm{ab}$ & $0.011 \mathrm{ab}$ & $0.019 \mathrm{a}$ \\
\hline 4,000 & $0.014 \mathrm{ab}$ & $0.014 \mathrm{ab}$ & $0.015 \mathrm{ab}$ & $0.011 b$ \\
\hline
\end{tabular}

Keterangan: Angka diikuti huruf berbeda pada peubah yang sama pada masing-masing perlakuan menunjukkan berbeda nyata pada taraf $5 \%$ dengan uji Tukey. MST $=$ minggu setelah tanam

hara P dan K serta berbagai cekaman abiotik lainnya (Saade et al., 2018). Pengikatan ion $\mathrm{Na}^{+}$ke komponen dinding sel dapat mempengaruhi pengikatan ion lain dan menghambat fungsi pektin selama pertumbuhan sel. Mekanisme adaptasi yang terjadi pada struktur dinding sel dapat dimanfaatkan untuk pemuliaan tanaman jagung toleran garam.

Hasil analisis kadar $\mathrm{P}$ dan $\mathrm{K}$ oleh ke empat varietas jagung disajikan pada Tabel 3. Tabel 3 memperlihatkan adanya keragaman hasil analisis pada semua varietas jagung terhadap persentase kadar $\mathrm{K}^{+}$. Varietas Pioneer 22, Bisi 12, dan Bisma mengalami peningkatan kadar $\mathrm{K}$ masingmasing sebesar $4.65,1.53$, dan 1.80 kali dibandingkan pada kondisi tanpa stres $\mathrm{NaCl}$. Persentase kadar $\mathrm{K}^{+}$tertinggi pada kondisi tercekam $\mathrm{NaCl}$ terjadi pada varietas Pioneer 22 yaitu $0.407 \%$ dan terendah pada varietas Sukmaraga yaitu $0.075 \%$. Penyerapan $\mathrm{K}^{+}$yang tinggi sangat penting bagi tanaman jagung untuk beradaptasi terhadap cekaman salinitas. Akumulasi $\mathrm{K}^{+}$yang tinggi juga terkait dengan hasil biji-bijian yang lebih tinggi (Asif et al., 2018). Perbedaan kemampuan tersebut diduga mempengaruhi potensi hasil panen dari kedua varietas tersebut. Potensi hasil panen Pioneer 22 mencapai $10.8 \mathrm{Mg} \mathrm{ha}^{-1}$ sedangkan Sukmaraga hanya $8.5 \mathrm{Mg} \mathrm{ha}^{-1}$ (Adnan et al., 2010).

Keragaman peningkatan kadar $\mathrm{PO}_{4}^{-}$pada kondisi tercekam $\mathrm{NaCl}$ juga terjadi pada varietas Pioneer 22, Bisma, dan Sukmaraga, berturut-turut 0.40, 0.05, dan 0.32 kali, sedangkan pada varietas Bisi 12 mengalami penurunan sebesar 0.29 kali. Persentase kadar $\mathrm{PO}_{4}^{-}$tertinggi terdapat pada varietas Pioneer 22 , yaitu $0.120 \%$, sedangkan terendah pada varietas Bisi 12 yaitu $0.056 \%$ (Tabel 3 ).
Kelarutan $\mathrm{NaCl}$ menyebabkan cekaman pada tanaman sehingga terjadi penurunan potensial air tanah yang menyebabkan tanaman defisiensi air. Hal ini terjadi karena potensial air lingkungan lebih negatif dibandingkan potensial air pada jaringan akar sehingga tanaman kehilangan air, walaupun air tersedia dalam jumlah banyak. Selain itu, $\mathrm{Na}$ yang tinggi menyebabkan terjadinya keracunan sehingga menyebabkan kerusakan membran permeabel sel perakaran. Gejala gangguan pertumbuhan diantaranya adalah penurunan jumlah anakan, dan hambatan pertumbuhan akar, daun serta produksi (Chen et al., 2017). Unsur $\mathrm{Cl}^{-}$merupakan hara mikro yang diperlukan dalam jumlah sedikit untuk kegiatan fotosintesis yang berhubungan dengan produksi oksigen dan phytohormone (Gharbi et al., 2017a).

Hasil percobaan terhadap karakter fisiologi cekaman salinitas pada beberapa varietas padi dalam kaitan metabolisme nitrat, amonium, dan nitrit menunjukkan adanya perbedaan tanggap terhadap metabolisme $\mathrm{NO}_{3}^{-}$, $\mathrm{NH}_{4}^{+}$, dan $\mathrm{NO}_{2}^{-}$(Utama, 2010). Demikian juga metabolisme $\mathrm{K}^{+}$dan $\mathrm{PO}_{4}^{-}$yang terjadi pada jagung Pioneer 22, Bisi 12, Bisma, dan Sukmaraga. Secara morfologi cekaman tersebut mempengaruhi pertumbuhan daun menjadi lebih kecil dan warna akar lebih coklat (Gambar 1). Hal ini diduga berhubungan dengan karakteristik dinding sel yang berubah sebagai respons terhadap cekaman garam bersamaan dengan perubahan komposisi kimia (Meng et al., 2016).

Tajuk dan akar varietas toleran mampu merespons dengan memodulasi metabolisme, ekspresi gen, dan aktivitas protein yang mampu menghasilkan perubahan komposisi dinding sel, proses transportasi, ukuran dan

Tabel 3. Persentase kadar $\mathrm{K}^{+}$dan $\mathrm{PO}_{4}^{-}$pada beberapa varietas jagung tercekam $\mathrm{NaCl}$ umur 3 MST pada kultur hara

\begin{tabular}{|c|c|c|c|c|}
\hline $\begin{array}{l}\text { Konsentrasi } \\
\mathrm{NaCl}\left(\mathrm{mg} \mathrm{kg}^{-1}\right)\end{array}$ & Pioneer 22 & Bisi 12 & Bisma & Sukmaraga \\
\hline & \multicolumn{4}{|c|}{$\mathrm{K}^{+}(\%)$} \\
\hline 0 & $0.072 b c$ & $0.092 b c$ & $0.064 \mathrm{c}$ & $0.100 \mathrm{bc}$ \\
\hline 4,000 & $0.407 \mathrm{a}$ & $0.233 \mathrm{ab}$ & $0.179 b$ & $0.075 b c$ \\
\hline 0 & \multicolumn{4}{|c|}{$\mathrm{PO}_{4}^{-}(\%)$} \\
\hline 4,000 & $0.120 \mathrm{a}$ & $0.056 \mathrm{c}$ & $0.080 b c$ & $0.098 \mathrm{ab}$ \\
\hline
\end{tabular}

Keterangan: Angka diikuti huruf berbeda pada peubah yang sama pada masing-masing perlakuan menunjukkan berbeda nyata pada taraf 5\% dengan uji Tukey. MST = minggu setelah tanam 


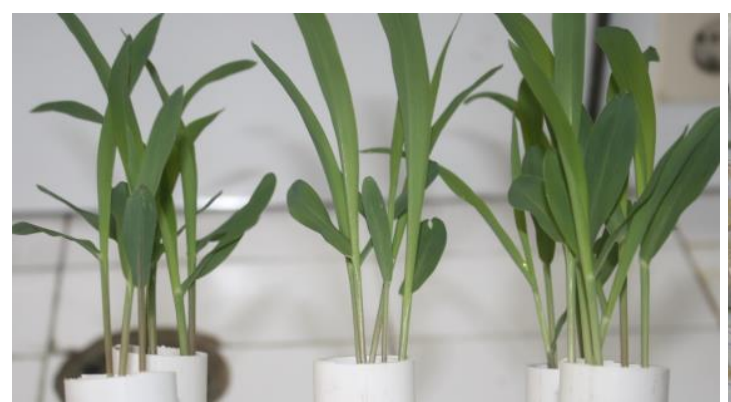

A

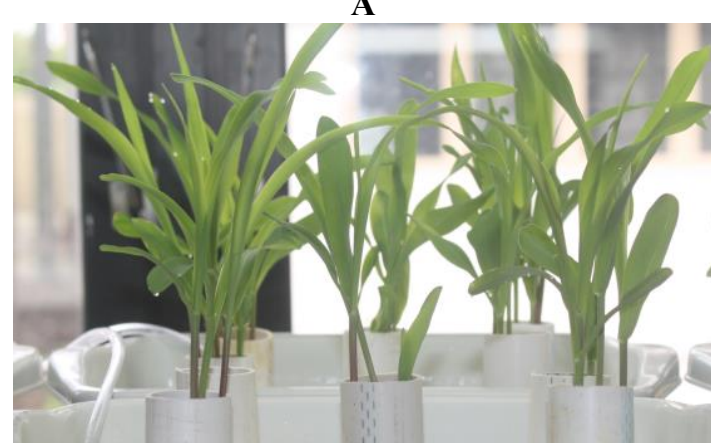

B

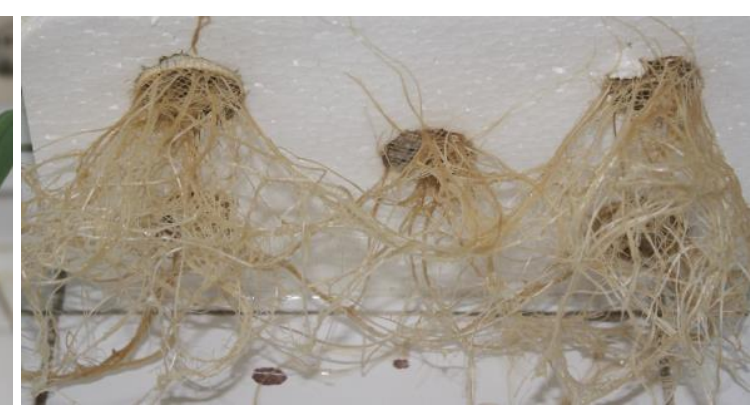

A

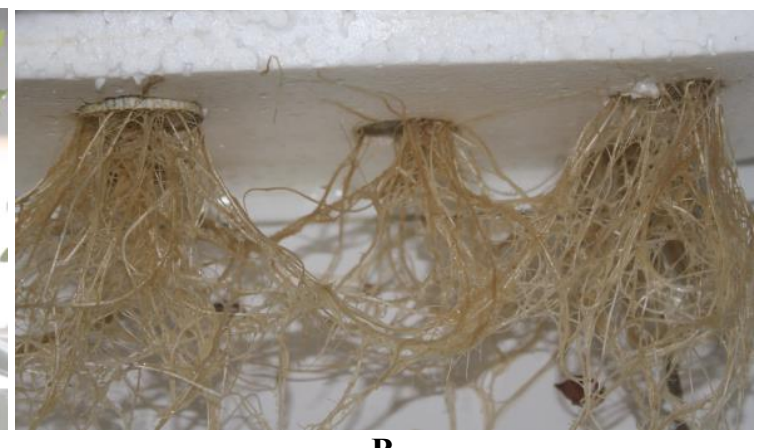

B

Gambar 1. Pertumbuhan daun 2 minggu setelah tanam (MST) dan akar jagung 3 minggu setelah tanaman (MST) pada kondisi tanpa cekaman (A) dan pertumbuhan daun dan akar pada kondisi tercekam garam (B)

bentuk sel, dan arsitektur akar. Cekaman garam menginduksi perubahan komposisi dinding sel akar yang berfungsi mencegah kehilangan air dan mengubah jalur transportasi ion. Pengikatan ion $\mathrm{Na}^{+}$ke komponen dinding sel dapat mempengaruhi $\mathrm{Na}^{+}$, pengikatan ion lain, dan menghambat fungsi pektin selama pertumbuhan sel (Munns dan Tester, 2008; Deinlein et al., 2014).

Modifikasi yang terjadi pada dinding sel tertentu akan mempengaruhi pergerakan zat terlarut dan air, membantu mencegah kehilangan air serta masuknya $\mathrm{Na}^{+}$dan $\mathrm{Cl}^{-} \mathrm{ke}$ dalam sel atau xilem yang berlebihan. Penghalang difusi akar tidak hanya mencegah ion masuk, tetapi juga berperan sebagai penghalang keluarnya ion $\mathrm{K}^{+}$dan air. Perubahan ini bermanfaat bagi tanaman untuk mencegah kehilangan air dan mengubah jalur transportasi ion. Pengikatan ion $\mathrm{Na}^{+}$ke komponen dinding sel dapat mempengaruhi bagian $\mathrm{Na}^{+}$, mempengaruhi pengikatan ion lain, dan menghambat fungsi pektin selama pertumbuhan sel (Byrt et al., 2018). Toleransi cekaman $\mathrm{NaCl}$ varietas toleran diduga karena kemampuannya yang lebih besar dalam menyerap anion dan kation walaupun pada kondisi tercekam (Munns et al., 2019).

\section{KESIMPULAN}

Kemampuan adaptasi jagung hibrida dan komposit terhadap cekaman $\mathrm{NaCl}$ terjadi melalui mekanisme fisiologi metabolisme anion dan kation. Perbedaan persentase kadar $\mathrm{NO}_{3}^{-}, \mathrm{NO}_{2}^{-}, \mathrm{PO}_{4}^{-}, \mathrm{NH}_{4}^{+}$, dan $\mathrm{K}^{+}$antara varietas jagung hibrida (Pioneer 22 dan Bisi 12) dan komposit (Bisma dan Sukmaraga), menunjukkan perbedaan kemampuan adaptasi varietas jagung terhadap cekaman salinitas terutama pada varietas hibrida.

\section{UCAPAN TERIMA KASIH}

Ucapan terima kasih, penulis sampaikan kepada DRPM, Kemenristekdikti RI yang telah berkenan membantu biaya penelitian ini, melalui program penelitian kompetitif nasional. Ucapan yang sama juga disampaikan kepada Bapak Zaitul Hamid dan Budi yang telah banyak membantu dalam pelaksanaan kegiatan penelitian di laboratorium.

\section{DAFTAR PUSTAKA}

Adnan, A.M., C. Rapar, Zubachtirodin. 2010. Deskripsi varietas unggul jagung. Pusat Penelitian dan Pengembangan Tanaman Pangan, Kementan. Balai Penelitian Tanaman Serealia, Maros. Edisi Keenam.

Anonim. 2007. Spectroquant Thermoreator TR Nova 420 manual versi bahasa Indonesia. Tim Merck, Jerman, GE.

Asif, M.A., R.K. Schilling, J. Tilbrook, C. Brien, K. Dowling, H. Rabie, L. Short, C. Trittermann, A. Garcia, E.G.B. Lennard, B. Berger, D.E. Mather, M. Gilliham, D. Fleury, M. Tester, S.J. Roy, A.S. Pearson. 2018. Mapping of novel salt tolerance QTL in an Excalibur $\mathrm{x}$ Kukri doubled haploid wheat population. Theor. Appl. Genet. 131:2179-2196.

Byrt, C.S., R Munns, R.A. Burton, M. Gilliham. 2018. Root cell wall solutions for crop plants in saline soils. Plant Sci. 269:47-55. 
Chen, J., H. Zhang, X. Zhang, M. Tang. 2017. Arbuscular mycorrhizal symbiosis alleviates salt stress in black locust through improved photosynthesis, water status, and $\mathrm{K}^{+} / \mathrm{Na}^{+}$homeostasis. Front. Plant Sci. 8: Article 1739.

Deinlein, U., A.B. Stephan, T. Horie, W. Luo, G. Xu, J.I. Schroeder. 2014. Plant salt-tolerance mechanisms. Trends Plant Sci. 19:371-379.

Demidchik, V., D. Straltsova, S.S. Medvedev, G.A. Pozhvanov, A. Sokolik, V. Yurin. 2014. Stressinduced electrolyte leakage: the role of $\mathrm{K}^{+}$permeable channels and involvement in programmed cell death and metabolic adjustment. J. Exp. Bot. 65:12591270 .

Demidchik, V., E.V. Tyutereva, O.V. Voitsekhovskaja. 2017. The role of ion disequilibrium in induction of root cell death and autophagy by environmental stresses. Func. Plant Biol. 45:28-46.

Gharbi, E., J-P. Martínez, H. Benahmed, I. Hichri, P.I. Dobrev, V. Motyka, M. Quinet, S. Lutts. 2017a. Phytohormone profiling in relation to osmotic adjustment in $\mathrm{NaCl}-$ treated plants of the halophyte tomato wild relative species Solanum chilense comparatively to the cultivated glycophyte S. lycopersicum. Plant Sci. 258:77-89.

Gharbi, E., J.P. Martínez, H. Benahmed, H. Dailly, M. Quinet, S. Lutts. 2017b. The salicylic acid analog 2,6dichloroisonicotinic acid has specific impact on the response of the halophyte plant species $S$. chilense to salinity. Plant Growth Regul. 82:517-525.

Haryoko, W., Kasli, I. Suliansyah, A. Syarif, T.B. Prasetyo. 2012. Toleransi beberapa varietas padi pada sawah gambut berkorelasi dengan kandungan asam fenolat. J. Agron. Indonesia. 40:112-118.

Ismail, A., S. Takeda, P. Nick. 2014. Life and death under salt stress: same players, different timing? J. Exp Bot. 65:2963-2979.

Lashari, M.S., B.N. Mangan, I. Rajpar, H. Ji, G. Pan, A.A. Lashari, J. Nan. 2018. Improvement of soil fertility and crop yield through biochar amendment from salt affected soil of central china. J. Agric. Sci. and Tech. B8:209-219.

Meng, S., L. Su, Y.Li, Y.Wang, C. Zhang, Z. Zhao. 2016. Nitrate and Ammonium Contribute to the Distinct Nitrogen Metabolism of Populus simonii during Moderate Salt Stress. PLoS ONE 11:1-16.
Merck. 2007. Spectroquant Thermoreator TR Nova 420 manual versi bahasa Indonesia, Tim Merck, Jerman, GE.

Munns, R., M. Tester. 2008. Mechanisms of Salinity Tolerance. Annu. Rev. Plant Biol. 59:651-81.

Munns, R., B Arsova., B. Barkla., J. Bose. 2019. Energy costs of salinity tolerance in crop plants. New Phyt. 221:25-29.

Munns, R., M. Gilliham. 2015. Salinity tolerance of crops, what is the cost? New Phytol. 208:668-673.

Pongprayoon, W., R. Tisarum, C. Theerawittaya, S. Chaum. 2019. Evaluation and clustering on salt-tolerant ability in rice genotypes (Oryza sativa L. subsp. indica) using multivariate physiological indices. Physiol. Mol. Biol. Plants. 2019:1-11.

Putri, P.H., G.W.A. Susanto, A. Taufiq. 2017. Toleransi Genotipe Kedelai terhadap Salinitas. Penelitian Pertanian Tanaman Pangan. 3:233-242.

Rachman, A., A. Dariah, S. Sutono. 2018. Pengelolaan sawah salin berkadar garam tinggi. Jakarta, IAARD Press.

Ritung, S., E. Suryani, D. Subardja, Sukarman, K. Nugroho, Suparto, Hikmatullah, A. Mulyani, C. Tafakresnanto, Y. Sulaeman, R.E. Subandiono, Wahyunto, Ponidi, N. Prasodjo, U. Suryana, H. Hidayat, A. Priyono, W. Supriatna. 2015. Sumber Daya Lahan Pertanian Indonesia Luas, Penyebaran, dan Potensi Ketersediaan. Badan Penelitian dan Pengembangan Pertanian, Jakarta. IAARD Press.

Rustikawati, M. Simarmata, E. Turmudi, C. Herison. 2014. Penentuan Kadar Garam Kultur Hara untuk Seleksi Toleransi Salinitas pada Padi Lokal Bengkulu. J. Akta Agrosia 17:101-107.

Saade, S., S. Negrão, D. Plett, T. Garnett, M. Tester. 2018. Genomic and Genetic Studies of Abiotic Stress Tolerance in Barley. Springer International Publishing AG, part of Springer Nature 2018259 N. Stein, G.J. Muehlbauer (Eds.), The Barley Genome, Compendium of Plant Genomes. 2018:259-286.

Sahrawat, K.L. 2010. Reducing iron toxicity in lowland rice with tolerant genotypes and plant nutrition. J. Plant Stress 4:70-75. 
Shabala, S., V. Demidchik, L. Shabala, T.A. Cuin, S.J. Smith, A.J. Miller, J.M. Davies, I.A. Newman. 2006. Extracellular $\mathrm{Ca}^{2+}$ ameliorates $\mathrm{NaCl}$-induced $\mathrm{K}^{+}$loss from Arabidopsis root and leaf cells by controlling plasma membrane $\mathrm{K}^{+}$-permeable channels. Plant Physiol 141:1653-1665.

Susanto, R. 2019. Informasi Daerah Rawa dan Pesisir. Pusdatarawa. https://www.google.com [31 Maret 2019].

Utama, M.Z.H. 2008. Mekanisme fisiologi toleransi cekaman aluminium pada spesies legum penutup tanah terhadap metabolisme Nitrat $\left(\mathrm{NO}_{3}^{-}\right)$, Amonium $\left(\mathrm{NH}_{4}^{+}\right)$, dan Nitrit $\left(\mathrm{NO}_{2}^{-}\right)$. Bul. Agron. 36:175-179.
Utama, M.Z.H. 2010. Effect of NaCl-stress on metabolism of $\mathrm{NO}_{3}^{-}, \mathrm{NH}_{4}^{+}$and $\mathrm{NO}_{2}^{-}$at several rice varieties. J. Trop. Soils 15:189-194.

Utama, M.Z.H., W. Haryoko, R. Munir, Sunadi. 2009. Penapisan varietas padi toleran salinitas pada lahan rawa Di Kabupaten Pesisir Selatan. J. Agron. Indonesia 37:101-106.

Zorb, C., C.M. Geilfus, K.J. Dietz. 2019. Salinity and crop yield. Plant Biol. 21:31-38. 